aureus. Ann Intern Med 1982;97:309-317.

3. Peacock JE, Marsik FC, Wenzel RP. Methicillin-resistant Staphylococcus aureus: introduction and spread within a hospital. Ann Intern Med 1980;93:526-532.

4. Arnow PM, Allyn PA, Nichols EM, Hill DL, Pezzlo MA, Bartlett RH. Control of methicillin-resistant Staphylococcus aureus in a burn unit: role of nurse staffing. I Trauma 1982;22:954-959.

5 . Boyce JM. Should we vigorously try to contain and control methicillin-resistant Staphylococcus aureus? Infect Control Hosp Epidemiol 1991;12:46-54.

6. Phillips LG, Heggers JP, Robson MC. Burn and trauma units as sources of methicillin-resistant Staphylococcus aureus. J Burn Care Rehabil 1992;13:293-297.

7. Boyce JM. Burn units as a source of methicillin-resistant Staphylococcus aureus infections. JAMA 1983;249:2803-2807.

8. Snyder LL, Wiebelahus P, Boon SE, Morin RA, Goering R. Methicillin-resistant Staphylococcus aureus eradication in a burn center. J Burn Care Rehabil 1993;14:164-168.

9. Haley RW. Methicillin-resistant Staphylococcus aureus: do we just have to live with it? Ann Intern Med 1991;114:162-164.

10. Mylotte JM. Control of methicillin-resistant Staphylococcus aureus: the ambivalence persists. Infect Control Hosp Epidemiol 1994;15:73-77.
11. National Committee for Clinical Laboratory Standards. Methods for dilution antimicrobial susceptibility tests for bacteria that grow aerobically. Villanova, PA: NCCL Standards; 1993. Approved standard. Document M7-A3.

12. Pfaller MA, Hollis RJ, Sader HS. Chromosomal restriction fragment analysis by pulsed-field gel electrophoresis. In: Isenberg HD, ed. Clinical Microbiology Procedures Handbook. Washington, DC: American Society for Microbiology; 1994(suppl 1):1-12.

13. Boyce JM, Jackson MM, Pugliese G, et al. Methicillin-resistant Staphylococcus aureus (MRSA): a briefing for acute care hospitals and nursing facilities. Infect Control Hosp Epidemiol 1994;15:105-115.

14. Trilla A, Nettleman MD, Hollis RJ, Fredrickson M, Wenzel RP, Pfaller MA. Restriction endonuclease analysis of plasmid DNA from methicillin-resistant Staphylococcus aureus: clinical application over a three-year period. Infect Control Hosp Epidemiol 1993;14:29-35.

15. Reboli AC, John JFJ, Platt CG, Cantey JR. Methicillin-resistant Staphylococcus aureus at a Veterans' Affairs medical center: importance of carriage of the organism by hospital personnel. Infect Control Hosp Epidemiol 1990;11:291-296.

\title{
Intrinsic Contamination Prompts Recall of Albumin
}

\section{Gina Pugliese, RN, MS Martin S. Favero, PhD}

The US Food and Drug Administration has advised the public of a voluntary manufacturer's recall of all Albuminar brand human albumin and Plasma Plex brand plasma protein fraction because of reports of bacterial sepsis with Enterobacter cloacae associated with receipt of Centeon Albumin (Human), Albuminar-25, Lot no. P61205. On October 9, 1996, the manufacturer, Centeon, L.L.C. (King of Prussia, PA), after consultation with the FDA, announced the recall of all lots of Albuminar and Plasma Plex products. This includes Albumin, 5\%, 20\%, 25\% (Human), U.S.P. (Albuminar -5, Albuminar -20, Albuminar -25), and Plasma Protein Fraction, (Human)
U.S.P. 5\% Solution Heated-Treated (Plasma-Plex, PPF), distributed under the Centeon or Armour label. This recall does not apply to any other Centeon products or to albumin or plasma protein fraction produced by other companies. Hospitals, dialysis centers, and other users should discontinue the use of all lots of Centeon/Armour Albuminar and Plasma-Plex, quarantine all vials, and contact their distributor or Centeon for instructions on how to return them.

Healthcare professionals should report any episode of infection associated with these products to the CDC's Hospital Infections Program, National Center for Infectious Disease, by telephoning 404-639-6413, or by faxing 404-639-6459. Episodes also should be reported to the FDA's Medwatch Program, by telephoning $800-332-1088$, or by faxing $800-332-$ 0178 .

Health centers having difficulty obtaining alternative sources of albumin should contact the FDA's Biologics Supply Office, telephone 301-827-0379.

FROM: Food and Drug Administration. FDA advises public of voluntary worldwide recall of all Albuminar and Plasma-Plex Manufacturer by Centeon, L.L.C. Press Release October 9, 1996.

Centers for Disease Control and Prevention. Voluntary worldwide recall of Albuminar and Plasma-Plex by Centeon L.L.C. MMWR 1996; 45(41):892. 